\title{
Að læra íslensku sem annað mál: Markviss orðaforðakennsla í útinámi
}

\author{
Harpa Sif Porsteinsdóttir og Rannveig Oddsdóttir
}

Abstract Um höfunda $\backslash$ About the authors $>$ Heimildir

Börnum af erlendum uppruna hefur fjölgað mikið í íslenskum leikskólum á undanförnum árum. Rannsóknir sýna að staða pessara barna í íslensku er fremur slök og meiri pekkingu og úrræði vantar innan leikskólanna til að geta sem best stutt við máltöku íslenskunnar hjá peim. Markmið pessarar rannsóknar var að leita leiða til að vinna á markvissan hátt með íslenskan orðaforða leikskólabarna sem læra íslensku sem annað mál. Fimm tvítyngd börn fengu markvissa orðaforðakennslu með námsefninu Orðaleik í sjö vikur. Kennslan fór fram í útikennslu og var lögð áhersla á að kenna orð sem tengjast útiveru og umhverfi. Orðaforði barnanna var metinn fyrir íhlutun, strax að lokinni íhlutun og tveimur mánuðum eftir að henni lauk. Niðurstöður voru pær að öll börnin bættu við orðaforða sinn meðan á íhlutuninni stóð og viðhéldu peim orðaforða tveimur mánuðum síðar. Framfarir einstakra barna voru pó mismiklar og draga má pá ályktun af gögnum rannsóknarinnar að virkni barnanna í málörvunarstundunum og samskiptum innan leikskólans hafi áhrif á hve miklum framförum pau ná. Niðurstöður rannsóknarinnar sýna að orðaforðakennsla sem er fléttuð inn í daglegt leikskólastarf getur skilað góðum árangri en huga purfi að virkni einstakra barna í slíkum stundum og samskiptum innan leikskólans almennt.

Efnisorð: Orðaforði, tvítyngi, orðaforðakennsla, útikennsla, Orðaleikur

\section{Inngangur}

Börnum af erlendum uppruna hefur fjölgað mikið í íslenskum leikskólum á undanförnum árum. Rannsóknir sýna að staða pessara barna í íslensku er fremur slök og meiri pekkingu og úrræði vantar innan leikskólanna til að geta sem best stutt við máltöku íslenskunnar hjá peim (Aneta Figlarska o.fl., 2017). Markmið rannsóknarinnar sem hér er kynnt var að meta árangur af vinnu með námsefnið Orðaleik sem er nýtt íslenskt efni ætlað til að kenna grunnorðaforða íslenskunnar (Rannveig Oddsdóttir og Íris Hrönn Kristinsdóttir, 2018). Námsefnið var notað í útikennslu með fimm tvítyngdum börnum í sjö vikur og lögð áhersla á að kenna orðaforða sem tengist útiveru og umhverfi.

Í greininni er leitað svara við tveimur rannsóknarspurningum:

- Hvernig hentar námsefnið Orðaleikur til að efla orðaforða barna í gegnum leik og útikennslu?

- Hvaða áhrif hefur kennslan á orðaforða barnanna?

\section{Málproski tvítyngdra barna}

Börn læra móðurmál sitt svo að segja af sjálfu sér ef pau eru í virku málumhverfi. Í samskiptum við aðra læra pau orð og hugtök um hluti og athafnir í sínu daglega lífi (Bloom, 2000) og átta sig smám saman á hvernig tungumálið er uppbyggt og geta farið að tjá sig í skiljanlegum setningum (Sigríður 
Sigurjónsdóttir, 2005). Máltakan er samt sem áður mjög háð ytri áhrifum og pað hversu hröð framvindan verður ræðst að stórum hluta af pví málumhverfi sem einstaklingar hafa aðgang að (Hoff, 2006).

Mörg börn alast upp í umhverfi par sem fleiri en eitt tungumál eru notuð. Á pað til dæmis við um börn foreldra af erlendum uppruna par sem annað tungumál er talað á heimilinu en í samfélaginu og börn foreldra sem eru af ólíku pjóðerni. Tvítyngd börn læra mál eftir sömu leiðum og eintyngd börn en par sem tungumálakunnátta peirra dreifist á tvö mál verður framvindan í hvoru máli fyrir sig ekki sú sama og hjá eintyngdum jafnöldrum peirra (Hoff og Core, 2013; Meisel, 2004). Rannsóknir sýna til að mynda að börn sem tala tvö tungumál hafa yfirleitt minni orðaforða í hvoru tungumáli fyrir sig en eintyngd börn en samanlagður orðaforði peirra í báðum málunum er hins vegar stærri en orðaforði eintyngdra barna (Bialystok o.fl., 2010; Thordardottir o.fl., 2006). Hversu sterkur orðaforðinn verður í hvoru tungumáli fyrir sig veltur á hve ríkulegt málumhverfið er í viðkomandi tungumáli (Thordardottir, 2011). Oft er framvindan í öðru tungumálinu hraðari en í hinu. Hjá börnum sem alast upp við eitt tungumál á heimili en annað í samfélaginu er tungumál foreldranna yfirleitt sterkara málið fyrstu árin en samfélagsmálið styrkist pegar börnin fara að verja meiri tíma utan heimilisins (Gathercole og Thomas, 2009; Mieszkowska o.fl., 2017). Hversu hratt og hve vel börn ná tökum á seinna málinu er háð ýmsum páttum. Par getur til dæmis skipt máli hvort tungumálið er skylt fyrsta máli barnsins (Sigríður Ólafsdóttir, 2015), viðhorf barnsins og fjölskyldu pess til að læra málið (Oroujlou og Vahedi, 2011) og sá stuðningur sem pau fá við að læra nýja málið (Hoff og Core, 2013; Unsworth, 2016).

Nýleg rannsókn (Aneta Figlarska o.fl., 2017) á orðaforða 4-5 ára pólskra barna sem eiga báða foreldra pólska og hafa búið á Íslandi frá fæðingu eða fyrstu mánuðum ævi sinnar, sýndi fram á að pólskur orðaforði pessara barna var álíka mikill og orðaforði eintyngdra pólskra barna. Aftur á móti var íslenskur orðaforði peirra mun minni heldur en hjá eintyngdum íslenskum börnum. Рað er mjög jákvætt hve vel pessi börn standa í móðurmáli sínu á pessum aldri og eðlilegt að íslenskan sé veikara tungumálið hjá peim par sem pau hafa verið mikið í pólsku málumhverfi. Ef vel er staðið að kennslu pessara barna ætti munurinn að minnka með tímanum auk pess sem góð tök á móðurmáli geta stutt við tileinkun annars tungumáls (Cummins, 2001). Pær rannsóknir sem gerðar hafa verið á málproska eldri tvítyngdra barna á Íslandi benda hins vegar til pess að betur purfi að styðja við íslenskunám peirra (Sigríður Ólafsdóttir, 2015; Thordardottir og Juliusdottir, 2013). Rannsókn Sigríðar Ólafsdóttur (2015) á próun orðaforða og lesskilnings tvítyngdra barna í 4.-8. bekk sýndi að íslenskur orðaforði barnanna var mun lakari en hjá eintyngdum íslenskum jafnöldrum og bilið milli hópanna óx heldur eftir pví sem á leið. Lesskilningur tvítyngdu barnanna var einnig slakari en hjá peim eintyngdu og hafði orðaforði peirra forspárgildi fyrir frammistöðu peirra í lesskilningi. Pessar niðurstöður eru í samræmi við niðurstöður úr rannsókn Elínar Pallar Pórðardóttur og Önnu Guðrúnar Júlíusdóttur (2013) par sem fylgst var með framvindu málproska hjá börnum sem læra íslensku sem annað mál. Pótt börnin bættu við kunnáttu sína var framvindan of hæg til að pau næðu að vinna upp pað forskot sem eintyngdu íslensku börnin höfðu. Niðurstöðurnar benda einnig til pess að framvindan sé almennt hægari en hjá börnum sem læra ensku sem annað mál. Par gæti bæði skipt máli að íslenska hefur flóknari málfræði en enska og er mál sem hefur lítið vægi í alpjóðlegu samhengi par sem fáir tala málið sem getur haft pau áhrif að börn sem læra íslensku sem annað mál sjái ekki tilganginn í að læra málið (Thordardottir og Juliusdottir, 2013). Einnig gæti skipt máli að pótt bæði Íslendingum og innflytjendum pyki mikilvægt að innflytjendur læri íslensku (Ómar Hjalti Sölvason o.fl., 2021) hafa Íslendingar tilhneigingu til að tala ensku við fólk af erlendum uppruna sem fækkar tækifærum peirra til að æfa sig í íslensku (Eiríkur Rögnvaldsson, 2020).

Pótt ástæður pess að börnum gangi hægar að læra íslensku sem annað mál en mörg önnur tungumál geti að einhverju leyti legið í eiginleikum tungumálsins og viðhorfi til pess að læra málið verður ekki litið fram hjá pví að skólarnir gegna mikilvægu hlutverki í pessu sambandi og par má án efa gera betur. Innflytjendur voru fáir á Íslandi par til fyrir fáeinum árum og pekking á málefnum pessa hóps pví lítil innan skólakerfisins. Pótt leik- og grunnskólakennarar séu allir af vilja gerðir að mæta pörfum barna af erlendum uppruna vantar oft á tíðum pekkingu innan skólanna á hvernig best sé að standa 
að íslenskukennslu peirra. Í rannsókn Anetu Figlarska, Rannveigar Oddsdóttur, Samúels Lefever og Hrafnhildar Ragnarsdóttur (2017) kemur til dæmis fram að deildarstjórar telja að bæði vanti tíma og mannauð inn í leikskólana til að geta veitt pessum börnum pá málörvun sem pau purfa. Svipaða sögu er að segja um grunnskólana. Í rannsókn Hermínu Gunnpórsdóttur, Stéphanie Barillé og Markusar Meckl (2017) á reynslu foreldra og kennara af námi og kennslu nemenda af erlendum uppruna kemur fram að grunnskólakennarar telja sig ekki fá nægan stuðning við að skipuleggja kennslu tvítyngdra nemenda. Peir segja að málefnum nemenda af erlendum uppruna hafi lítill gaumur verið gefinn í kennaranáminu og peir sem á annað borð fengu einhverja fræðslu um pann málaflokk töldu hana ekki hafa gefið peim nægilega traustan grunn til að vita hvernig peir geti skipulagt kennslu pessara nemenda. Peir telja heldur ekki vera nægilegt framboð af endurmenntunarnámskeiðum tengdum málefnum nemenda af erlendum uppruna.

\section{Orðaforðanám}

Orð eru grunneiningar málsins og orðaforði pví lykillinn að pví að ná tökum á tungumáli. Börn purfa orðaforða til pess að geta átt í samskiptum við aðra og til að geta skilið talað og ritað mál. Flest börn byrja að tjá sig með orðum í kringum eins árs aldur, orðaforðinn vex hægt til að byrja með en í kringum 18 mánaða aldur taka flest börn kipp í orðaforða sem upp frá pví vex hratt allt fram á unglingsár pegar draga fer úr vaxtarhraðanum (Bloom, 2000).

Orðanám barna fer fram daglega og í öllum aðstæðum (Bloom, 2000). Börn taka orð inn í orðaforðann pegar pau átta sig á merkingu peirra út frá pví samhengi sem pau eru notuð í eða pegar pau fá útskýringar á orðunum sem pau skilja ekki. Hversu hratt börn bæta við orðaforða sinn veltur á málumhverfinu sem pau hafa aðgang að. Par skiptir máli hversu mörg og fjölbreytt orð pau heyra (Hart og Risley, 1995) og hvort peir fullorðnu styðja við orðanám peirra með pví til dæmis að eiga samræður við pau, útskýra fyrir peim orð sem pau skilja ekki og hvetja pau til að nota tungumálið til að tjá sig (Bloom, 2000). Árangursríkasta leiðin til að efla orðaforða ungra barna er að kenna peim orðaforða í raunverulegum aðstæðum. Par gildir annars vegar að setja orð á pá hluti og athafnir sem börnin sjá, nota og taka pátt í og hins vegar að setja pau orð, sem ætlunin er að kenna börnunum, í samhengi sem hefur merkingu fyrir peim (Honig, 2017). Eigi til dæmis að kenna börnum orð sem tengjast íslenskri náttúru er áhrifaríkara að gera pað úti í náttúrunni par sem börnin hafa pau fyrirbæri sem orðin tákna fyrir framan sig, geta séð pau, preifað á peim, fundið fyrir peim, heyrt í peim og/eða pefað af peim en að kenna pau innandyra út frá myndum eða útskýringum sem börnin tengja jafnvel ekki við pað sem orðin raunverulega standa fyrir.

Lestur er líka mikilvægur pegar kemur að orðanámi barna. Í ritmáli er notaður annar og fjölbreyttari orðaforði en í talmáli svo börn sem mikið er lesið fyrir heyra og læra orð sem pau myndu ekki læra annars. Fjöldi rannsókna hefur sýnt fram á tengsl milli orðaforða barna og pess hve mikið er lesið fyrir pau (Zauche o.fl., 2016). Einnig hefur verið sýnt fram á að máli skiptir hvernig er lesið. Lestur par sem stoppað er við orð sem talið er að börnin pekki ekki fyrir og pau útskýrð fyrir börnunum skilar til dæmis meiru en lestur án slíkra útskýringa (Biemiller og Boote, 2006; Sigrún Alda Sigfúsdóttir o.fl., 2020) og einnig hefur pað jákvæð áhrif á orðaforðanámið að eiga samræður við börnin um efni bókanna sem lesnar eru pví pá fá börnin tækifæri til að nota orðin sjálf sem hjálpar til við að festa merkingu peirra í minni (McKeown og Beck, 2014; Zevenbergen og Whitehurst, 2003).

Rannsóknir á orðaforða sýna að gríðarlegur einstaklingsmunur getur verið á orðaforða jafnaldra barna (Hart og Risley, 1995; Hrafnhildur Ragnarsdóttir, 2015, 2018; Huttenlocher o.fl., 2010). Fjöldi rannsókna hefur sýnt að sá munur tengist félags- og efnahagslegri stöðu fjölskyldna og skýrist af pví að málumhverfi barna á efnameiri heimilum er ríkulegra en hjá peim efnaminni (Attig og Weinert, 2020; Hart og Risley, 1995; Hoff, 2006; Huttenlocher o.fl., 2010; Rowe, 2012). Pannig sýndi til dæmis rannsókn Hart og Risley (1995) að börn úr hástétt heyrðu allt að fjórum sinni fleiri orð á viku en börn úr lágstétt og seinni rannsóknir hafa leitt í ljós að foreldrar í hástétt tala á annan hátt við börnin sín en foreldrar í lægri stéttum. Peir fara til dæmis frekar út fyrir pað sem er hér og nú, svo sem með pví að útskýra fyrir börnunum, undirbúa pau fyrir eitthvað sem er að fara að gerast eða 
segja frá atburðum sem börnin hafa ekki upplifað sjálf (Rowe, 2012) en slík samtöl krefjast flóknari málnotkunar en spjall um pað sem barnið er að fást við hverju sinni.

Pótt minni stéttamunur sé á Íslandi en víða annars staðar birtist sams konar munur í rannsóknum á málproska íslenskra barna (Amalía Björnsdóttir o.fl., 2003; Hrafnhildur Ragnarsdóttir, 2015). Hrafnhildur Ragnarsdóttir $(2015,2018)$ gerði langtímarannsókn á orðaforða, hlustunarskilningi og málfræðipekkingu fjögurra til sex ára gamalla barna. Framfarir í pessum páttum málproska voru skoðaðar sem og tengsl á milli mælinga og við bakgrunnsbreytur. Rannsóknin sýndi að orðaforði barnanna jókst gífurlega mikið á pessum árum og fylgni var á milli frammistöðu barnanna í orðaforða, hlustunarskilningi og málfræði. Niðurstöðurnar sýndu einnig fram á mikinn einstaklingsmun á öllum mælingunum. Orðaforði peirra barna sem minnstan orðaforða höfðu við sex ára aldur var til dæmis svipaður orðaforða peirra barna sem best stóðu tveimur árum fyrr. Fylgni var á milli frammistöðu barnanna í málproskaprófunum og bakgrunnsbreyta eins og aldurs, menntunar og tekna foreldra, fjölda barnabóka á heimili og pess hve oft var lesið fyrir börnin.

Hafa má áhrif á orðaforðanám barna með markvissri kennslu. Safngreining Marulis og Neuman (2010) sýnir að ná má góðum árangri í orðaforðakennslu með beinni kennslu. Með pví er átt við að orðin eru útskýrð með beinum hætti og börnin síðan hvött til að nota pau í samhengi. Rannsóknir sýna einnig að pað umhverfi sem tvítyngdum börnum er búið í leikskólum getur haft áhrif á hvernig peim gengur að ná tökum á seinna málinu (Ramírez o.fl., 2021). Par geta pættir eins menntun kennaranna og reynsla peirra af að vinna með tvítyngdum börnum skipt máli (Cirino o.fl., 2007; Ramírez o.fl., 2019), hvernig peir skipuleggja starfið og umhverfið í leikskólanum (Cirino o.fl., 2007; Edyburn o.fl., 2019; Solari o.fl., 2016) og hversu mikið peir tala við börnin (Bowers og Vasilyeva, 2011; Grøver o.fl., 2018).

\section{Útinám}

Útinám er mikilvægur hluti af leikskólastarfi á Íslandi. Leikskólabörn verja hluta dagsins í útiveru á leikskólalóðinni og gjarnan er farið í vettvangsferðir um nágrenni skólans. Tilgangur útiverunnar er margpættur, en meðal pess sem íslenskir kennarar telja vera meginhlutverk hennar er að ýta undir leik og nám barnanna, efla líkamlega og andlega velferð, veita peim tækifæri til að taka áhættu og finna fyrir öryggi og hafa áhrif á viðhorf peirra til umhverfisins (Kristín Norðdahl, 2016). Margir kennarar hafa fundið að útivera hefur góð áhrif á börn og pau áhrif hafa verið staðfest með rannsóknum (Sigrún Helgadóttir og Páll Jakob Líndal, 2010). Náttúrulegt umhverfi hefur jákvæð áhrif á tilfinningar og líðan sem birtist meðal annars í að börn með ofvirkni og athyglisbrest eiga auðveldara með að halda einbeitingu og stýra hegðun sinni (Taylor og Kuo, 2011). Pá virðast börn sem búa í umhverfi par sem pau hafa greiðan aðgang að grænum svæðum síður próa með sér ofvirkni og athyglisbrest en börn sem hafa takmarkaðan aðgang að slíkum svæðum (Thygesen o.fl., 2020).

Líkt og aðrar stundir dagsins býður útiveran upp á fjölbreytt tækifæri til málörvunar, börnin læra heiti á hlutum, fyrirbærum og athöfnum sem tengjast útiverunni en pó aðeins ef pau heyra orðin notuð (Honig, 2017). Mikilvægt er að fylgja börnum sem læra íslensku sem annað mál eftir í útiveru og tryggja að pau heyri og tali um pað sem fyrir augu og eyru ber. Oft pekkja pau hugtökin á sínu móðurmáli pví pau hafa lært pau af foreldrum sínum en hafa fá tækifæri utan leikskólans til að læra pau á íslensku. Einnig er hægt að vera með skipulagðar málörvunarstundir úti par sem málörvunin er annaðhvort tengd pví sem fengist er við í útiverunni hverju sinni eða unnið er að verkefnum sem annars væru unnin inni.

\section{Аðferð}

Leikskólinn par sem rannsóknin fór fram er í péttbýli utan höfuðborgarsvæðisins. Í leikskólanum eru um 100 börn á aldrinum eins til sex ára á fimm deildum. Hátt hlutfall er af tvítyngdum börnum eða um 30\%. Annar höfunda greinarinnar vann sem leikskólakennaranemi pegar rannsóknin fór fram 
og vann að verkefninu í vinnutíma sínum með börnunum. Verkefnið var kynnt fyrir leikskólastjóra áður en farið var af stað með rannsóknina og veitti hann sampykki sitt fyrir henni. Einnig var verkefnið kynnt fyrir foreldrum barnanna og óskað eftir skriflegu sampykki fyrir pátttöku barnanna.

\section{Pátttakendur}

Pátttakendur rannsóknarinnar voru fimm tvítyngd börn; tveir strákar og prjár stelpur. Börnin komu af tveimur deildum og eiga pað sameiginlegt að eiga báða foreldra af erlendum uppruna. Talað er erlent tungumál heima fyrir og móðurmál peirra er pví annað en íslenska. Prjú barnanna voru í elsta árgangi leikskólans og tvö í næstelsta árgangi. Aldursmunurinn á milli elsta barns og yngsta voru átta mánuðir. Börnunum voru gefin dulnefni sem notuð voru til að aðgreina pau í rannsókninni. Börnin voru á aldrinum 4;7 ára til 5;3 ára og voru peim gefin nöfnin Gunnar, Svava, Sara, Óli og Jóna. Gunnar var elstur barnanna og Jóna yngst.

\section{Íhlutun}

Íhlutunin stóð í sjö vikur og á peim tíma vann rannsakandi markvisst með börnunum í 45-60 mínútur í senn, tvisvar til prisvar í viku. Vinnan fór að mestu fram utandyra, bæði innan leikskólagarðsins og utan hans. Einnig tengdi rannsakandi orðaforðann inn í daglegt starf á deildinni, svo sem samverustundir. Verkefni kennslustundanna voru mismunandi milli daga en allar miðuðu pær að pví að leggja inn orð sem tengjast útiveru og umhverfi barnanna. Við val á orðum til að kenna voru notuð orðapemu úr námsefninu Orðaleik: Orðanám i leikskóla (Rannveig Oddsdóttir og Íris Hrönn Kristinsdóttir, 2018). Orðaleikur er námsefni sem samið er fyrir tvítyngd börn sem læra íslensku sem annað tungumál. Uppistaðan í efninu eru myndir sem sýna orð og hugtök úr grunnorðaforða íslenskunnar, pað er orð sem er mikilvægt að börn kunni til að geta átt samskipti innan leikskólans og geta tjáð sig um helstu atriði daglegs lífs. Myndirnar eru notaðar til umræðu og leikja sem miða að pví að virkja börnin í að nota orðin í eigin tali og festa pau pannig í sessi. Orðapemun sem notuð voru í íhlutuninni voru veður, útileiksveði og umhverfið úti. Myndirnar sem tilheyra pessum orðapemum voru prentaðar út og plastaðar til að hægt væri að vinna með pær úti. Einnig voru útbúin bingóspjöld og fjársjóðskort par sem unnið var með hluta orðanna.

Í kennslustundunum var alltaf farið út enda markmiðið að tengja orðaforðakennsluna við útikennslu. Unnið var með eitt orðapema í einu, viku í senn, og farið tvisvar í gegnum hvert orðapema. Í síðustu vikunni fékk hvert orðapema einn dag. Áður en íhlutun hófst hafði verið útbúin kennsluáætlun par sem fram kom hvað yrði gert, hvenær og hvert yrði farið. Gerðar voru nokkrar undantekningar frá kennsluáætluninni pegar börnin voru með óskir um staði sem pau vildu fara á. Hver kennslustund byrjaði á að rifjað var upp hvað hafði verið gert í tímanum áður og rætt um pað við börnin. Síðan var unnið markvisst með ákveðinn hluta orðaforðans. Orðin voru lögð inn með pví að nota pau um hluti í umhverfinu og tengja pau við myndirnar úr Orðaleik. Pannig var börnunum til dæmis bent á fjall sem pau sáu í útiverunni og peim sýnd myndin úr Orðaleik. Myndirnar voru síðan notaðar til að virkja börnin í umræðum um viðkomandi orð og reynt að fá pau til að nota orðin sjálf, svo sem með pví að spila minnisspil og bingó með orðunum sem unnið var með hverju sinni. Stundum voru teknar með bækur sem tengdust umfjöllunarefninu og pær lesnar úti og einu sinni var farið í fjársjóðsleit par sem búið var að útbúa fjársjóðskort og börnin fengu vísbendingar til pess að elta. Pannig gengu börnin á milli leiktækjanna í garðinum og enduðu á að finna fjársjóðinn. Einnig var tæknin nýtt, spjaldtölva tekin með út og unnið með orðaforðann á pann hátt. Allir tímar enduðu á að rifjað var upp hvað hafði verið gert í tímanum og börnin voru spurð hvað peim hefði pótt skemmtilegast eða áhugaverðast.

Einnig var unnið með Orðaleiksmyndirnar í leikskólastarfinu inni á deild. Daglega var til dæmis valinn veðurfræðingur og hann setti fram veðurspá fyrir daginn. Hann fór út í glugga, fann til pær myndir sem pössuðu við veðrið og sagði hinum börnunum hvernig veðrið var. Einnig purfti veðurfræðingurinn að finna út hvernig væri best að klæða sig eftir veðri, finna til myndir með peim fötum sem hentuðu pann dag og segja hinum börnunum frá. 


\section{Gögn}

Gagnasöfnun var í formi dagbókarskrifa rannsakanda og orðaforðaprófa.

Rannsakandi skrifaði í dagbókina í hverri kennslustund. Hann skráði hvernig dagarnir gengu fyrir sig, hvort börnin væru virk, skráði framfarir hjá börnunum og upplifanir sínar, hvað hefði mátt fara betur og hvernig mætti bæta pað. Einnig skrifaði rannsakandi hjá sér hvernig námsumhverfið var, par eð kennslan fór sjaldnast fram á sama stað, auk athugasemda um veðrið og aðra pætti sem gátu haft áhrif á kennsluna.

Staða og framfarir barnanna í orðaforða voru metin með pví að kanna pekkingu peirra á peim orðum sem unnið var með áður en íhlutunin hófst, strax að henni lokinni og tveimur mánuðum eftir að henni lauk. Eitt og eitt barn var tekið afsíðis og prófað í ró og næði. Alltaf var byrjað á að prófa tjáningarorðaforða á undan viðtökuorðaforða. Til að prófa tjáningarorðaforða hjá börnunum voru búin til spjöld með myndum af hlutum og fyrirbærum sem börnin áttu að nefna. Börnunum var sýnd ein mynd í einu, spurt hvað væri á myndinni og pau svöruðu eftir bestu getu. Til að prófa viðtökuorðaforða notaði rannsakandinn sömu spjöld. Fimm spjöldum var raðað fyrir framan börnin og pau áttu að benda á myndina sem samsvaraði pví orði sem rannsakandinn spurði um. Útbúin voru skráningarblöð með öllum orðunum og merkt við pau orð sem börnin gátu nefnt sjálf pegar peim voru sýndar myndirnar (tjáningarorðaforði) og hve mörg orð pau pekktu pegar pau heyrðu pau (viðtökuorðaforði).

\section{Úrvinnsla}

Niðurstöður úr orðaforðaprófunum voru notaðar til að skoða stöðu og framfarir barnanna í orðaforða á peim tíma sem rannsóknin náði yfir, hjá hópnum í heild og einstökum börnum. Upplýsingar úr dagbókarskrifunum voru notaðar til að varpa frekara ljósi á nám peirra yfir veturinn, svo sem til að sjá hvort mæting peirra og pátttaka í verkefninu gæti skýrt árangur peirra.

\section{Niðurstöður}

Í pessum kafla eru niðurstöðum rannsóknarinnar gerð skil. Fyrst er framvindu hópsins gerð skil og skoðað hvernig frammistaðan próast frá forprófun til viðhaldsmælingar. Í framhaldi af pví er framvindan hjá hverju barni skoðuð nánar og að lokum er kannað hvaða orð börnin pekktu á hverjum tíma.

\section{Framvinda hópsins}

Niðurstöður forprófana á orðaforða barnanna sýndu mikinn einstaklingsmun í bæði viðtökuorðaforða og tjáningarorðaforða en jafnframt var nokkur munur á milli peirra priggja orðapema sem prófuð voru. Alls voru börnin spurð um merkingu 70 orða. Par af voru sjö orð úr orðapemanu veður, 47 orð úr orðapemanu umbverfið úti og 16 orð úr orðpemanu útileiksvaði. Eins og sjá má á Mynd 1 var staða barnanna í bæði tjáningar- og viðtökuorðaforða missterk í upphafi rannsóknarinnar. 


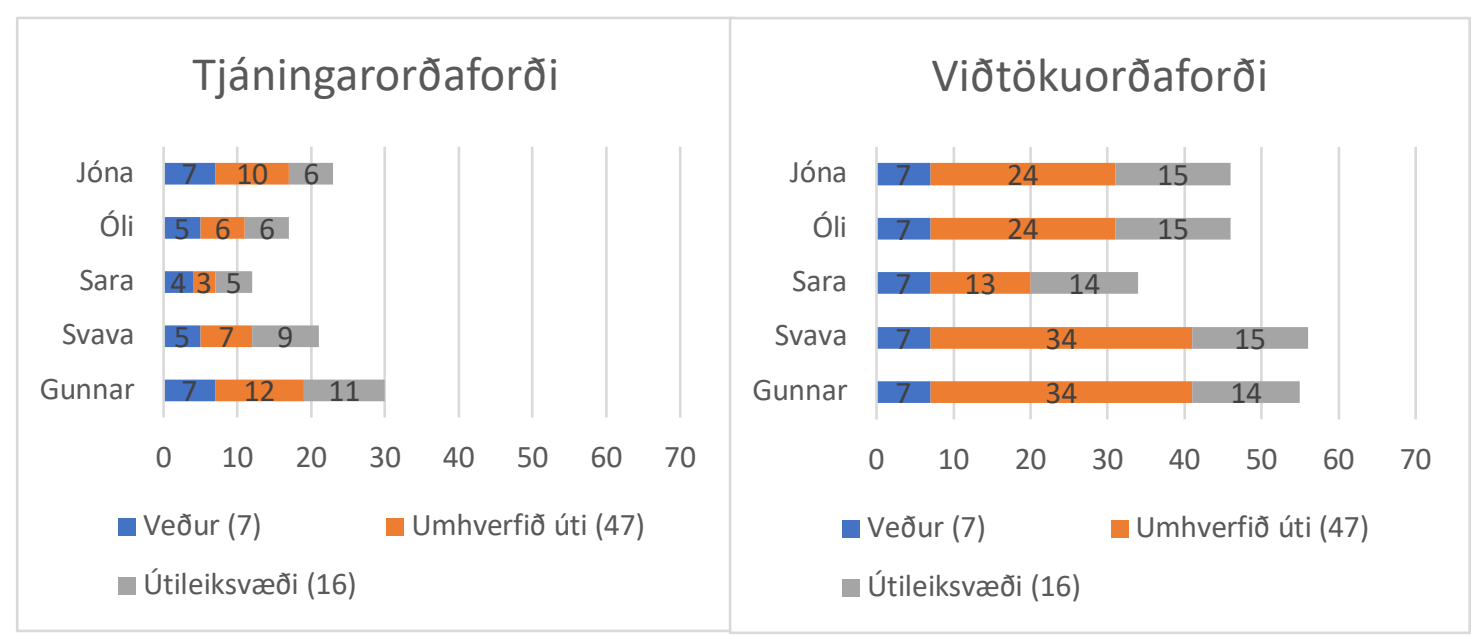

Mynd 1. Orðaforði barnanna fyrir íhlutun.

Mat á tjáningarorðaforða barnanna sýndi að pau kunnu að meðaltali 21 orð af peim 70 sem spurt var um. Sara sem kunni fæst pekkti 12 orð og Gunnar sem kunni flest pekkti 30 orð. Öll börnin pekktu hlutfallslega flest orð úr orðapemanu veður eða 4-7 orð af peim sjö orðum sem spurt var um. Hlutfallslega frst orð pekktu pau úr orðapemanu umbverfið úti eða 3-12 orð af 47. Úr orðapemanu útileiksvaði pekktu pau 5-11 orð af peim 16 orðum sem spurt var um.

Eins og við var að búast var viðtökuorðaforðinn stærri en tjáningarorðaforðinn en börnin pekktu að meðaltali 47 orð af peim 70 sem spurt var um. Líkt og í tjáningarorðaforðanum pekktu börnin hlutfallslega flest orð úr orðapemanu veður en öll börnin pekktu pau sjö orð sem spurt var um. Pá pekktu pau 14-15 af peim 16 orðum sem spurt var um úr orðapemanu útileiksvaði. Eins og í tjáningarorðaforðanum pekktu pau hlutfallslega fæst orð úr orðapemanu umbverfið úti og par kom einstaklingsmunurinn skýrast fram en börnin pekktu á bilinu 13-34 orð. Líkt og í tjáningarorðaforðanum var Sara pað barn sem fæst orð pekkti en Gunnar og Svava pekktu flest orð.

Öllum börnunum fór fram í bæði tjáningarorðaforða og viðtökuorðaforða á peim tíma sem rannsóknin náði yfir, en mismikið. Á Mynd 2 má sjá stöðu barnanna að íhlutun lokinni.

\section{Tjáningarorðaforði}

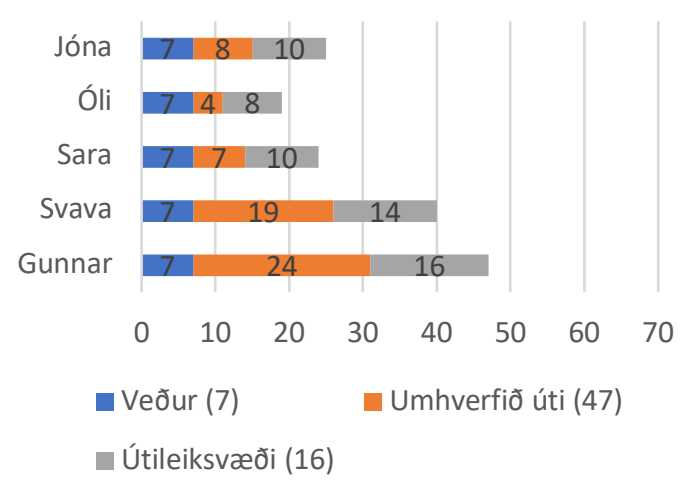

\section{Viðtökuorðaforði}

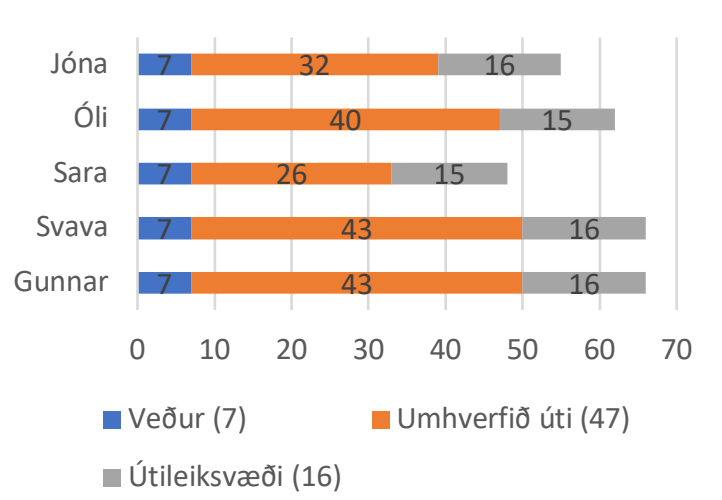

Mynd 2. Orðaforði barnanna eftir íhlutun.

Að meðaltali bættu börnin við sig 10 orðum í tjáningarorðaforða og 12 orðum í viðtökuorðaforða. Tjáningarorðaforðinn var pví að meðaltali 33 orð og viðtökuorðaforðinn 49 orð. Gunnar var áfram hæstur í tjáningarorðaforða með 47 orð og hann og Svava voru jöfn í viðtökuorðaforða með 66 orð. Sara var áfram lægst á mælingu á viðtökuorðaforða með 48 orð en var komin fram úr Óla í tjáningarorðaforða, pekkti 24 orð en Óli aðeins 19 orð. 
Eftir íhlutun pekktu öll börnin pau sjö orð í orðapemanu veður sem spurt var um, bæði í prófun á tjáningar- og viðtökuorðaforða. Mæling á viðtökuorðaforða sýndi einnig að prjú barnanna pekktu öll orðin í orðapemanu útileiksvaði og hin tvö öll nema eitt. Fleiri orð úr pví orðapema voru nú líka orðin hluti af virkum orðaforða barnanna en fyrir íhlutun. Meira vantaði upp á pekkingu barnanna á orðunum úr orðapemanu umhverfið úti. Í viðtökuorðaforða pekktu pau aðeins fjórðung peirra orða og Jóna og Óli pekktu bæði tveimur orðum færra úr pessu orðapema eftir íhlutun en fyrir hana. Meirihluti pessara orða var hins vegar kominn inn í viðtökuorðaforða barnanna eftir íhlutun, eða að meðaltali 37 orð af 47.

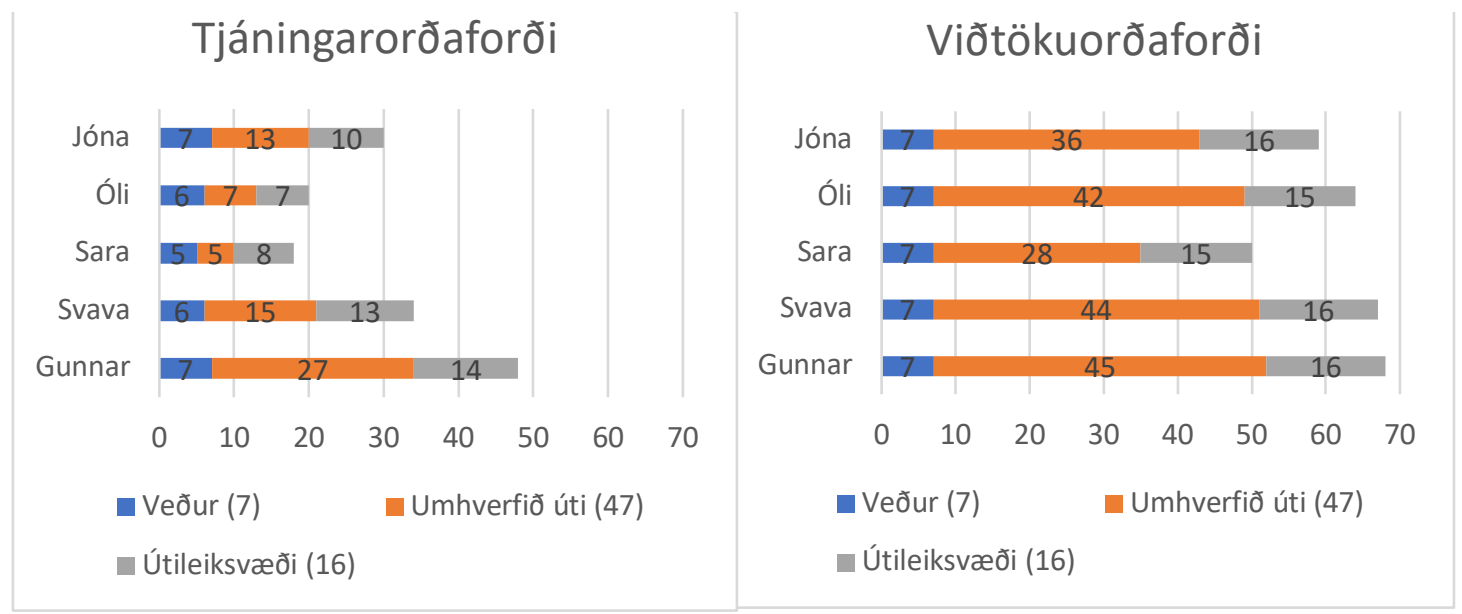

Mynd 3. Orðaforði barnanna tveimur mánuðum eftir að íhlutun lauk.

Á Mynd 3 má sjá niðurstöður úr viðhaldsmælingunni. Börnunum gekk almennt vel að viðhalda peim orðaforða sem pau tileinkuðu sér á íhlutunartímabilinu. Meðaltal hópsins í mælingu á tjáningarorðaforða var 30 orð, einu orði minna en strax eftir íhlutun. Gunnar, Óli og Jóna höfðu bætt við sig nokkrum orðum en Svava og Sara pekktu hins vegar færri orð en strax eftir íhlutun. Meðaltal hópsins í viðtökuorðaforða hafði hækkað um prjú orð og var 62 stig og par höfðu öll börnin bætt við sig orðum.

\section{Framfarir einstakra barna}

Pótt öllum börnunum færi fram á tímabilinu sem rannsóknin náði yfir voru framfarir peirra mismiklar eins og fram hefur komið. Á Mynd 4 má sjá framvinduna hjá hverju barni í tjáningar- og viðtökuorðaforða, pað er hve mörg orð bættust við orðaforða peirra eftir íhlutun og hvort pau viðhéldu peim orðaforða tveimur mánuðum síðar.
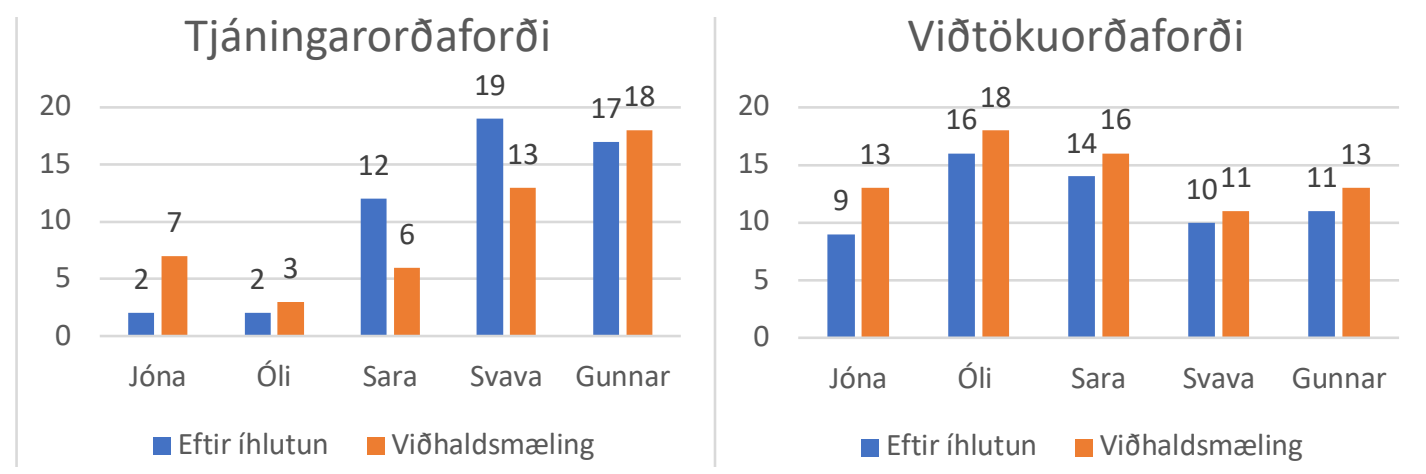

Mynd 4. Framfarir í orðaforða barnanna á rannsóknartímanum, fjöldi orða sem bættist við eftir íhlutun. 
Svava, Gunnar og Sara bættu mestu við tjáningarorðaforða sinn pær vikur sem íhlutunin stóð, 19, 17 og 12 orðum. Óli og Jóna bættu aftur á móti ekki við sig nema tveimur orðum. Í viðhaldsmælingunni höfðu Svava og Sara tapað 6 orðum hvor en hjá öðrum börnum bættust eitt til fimm orð við og athygli vekur að Jóna sem bætti aðeins tveimur orðum við sig á íhlutunartímanum hafði bætt við sig fimm orðum pegar koma að viðhaldsmælingunni.

Í viðtökuorðaforða voru framfarirnar jafnari. Óli og Sara bættu flestum orðum við sig pær vikur sem íhlutunin stóð, 16 og 14 orðum en Jóna fæstum, níu orðum. Öll börnin höfðu bætt einhverjum orðum við viðtökuorðaforðann pegar kom að viðhaldsmælingunni og aftur var pað Jóna sem bætti mestu við sig eða fjórum orðum.

Fjölskylduaðstæður pessara barna eru ólíkar. Pau mættu líka misvel í málörvunarstundirnar og hafa ólíkan persónuleika og áhugasvið sem getur hafa haft áhrif á framvinduna hjá peim.

\section{Gunnar}

Foreldrar Gunnars eru virkir pátttakendur í samfélaginu og leikur Gunnar mikið við íslensk börn, einnig á hann eldra systkini sem er nálægt honum í aldri. Gunnar er vinmargur og í vinahópnum eru bæði íslensk börn og börn með sama móðurmál og hann. Gunnar var pað barnanna sem skoraði hæst á mælingum á orðaforða í upphafi verkefnisins. İ tjáningarorðaforða var hann með 30 orð rétt áður en íhlutun hófst og 55 orð í viðtökuorðaforða.

Gunnar mætti vel í íhlutun og var mjög námfús. 18. nóvember 2019 skráir rannsakandi í dagbókina: „Gunnar er duglegur að sýna hve mikinn áhuga hann hefur á námsefninu og er duglegur að nota orðin fyrir utan tímana. Hann hefur áhuga á nærumhverfi sínu og er fljótur að taka inn orðin sem hann hefur áhuga á." 5. desember 2019 skráir rannsakandi: „Gunnari finnst erfitt að hleypa hinum börnunum að og á erfitt með að deila athygli kennarans með hinum börnunum. Petta er verkefni sem við purfum að vinna með.“

Áhugi og virkni Gunnars í málörvunarstundunum á eflaust sinn pátt í hve góðum framförum hann náði á íhlutunartímanum. Hann bætti 17 orðum við tjáningarorðaforðann og 11 orðum við viðtökuorðaforðann. Í viðhaldsmælingunni tveimur mánuðum síðar hafði Gunnar bætt enn frekar við orðaforða sinn, einu orði í tjáningarorðaforða og tveimur í viðtökuorðaforða. Gunnar var pví enn pað barn sem best stóð í orðaforða að íhlutun lokinni.

\section{Svava}

Foreldrar Svövu eru í nokkrum samskiptum við Íslendinga. Svava á eldra systkini sem er nálægt henni í aldri. Svava er félagslega sterk og á góða íslenska vini sem hún leikur sér við bæði innan og utan leikskóla. Svava var með ágætan orðaforða fyrir íhlutun. Í tjáningarorðaforða var hún með 21 orð rétt og í viðtökuorðaforðanum 56.

Hún var hins vegar pað barn sem var minnst áhugasöm um verkefnin og missti einnig úr nokkra tíma. Í dagbókarfærslu 21. nóvember 2019 skráir rannsakandi eftirfarandi: „Svava á enn pá erfitt með að stjórna sér. Hún reynir að stjórna með erfiðri hegðun og pað hefur mikil áhrif á hin börnin og tímana. Við höfum verið að vinna með petta og ég held að petta komi með tímanum, hún er að sjá hvað hún komist upp með.“ Nokkrum vikum síðar hefur staðan batnað og 9. desember 2019 skráir rannsakandi: „Svava hefur tekið miklum framförum. Tímarnir eru farnir að vera auðveldari fyrir hana og ég sé hvað henni er farið að líða betur. Hún er líka farin að sýna nærumhverfinu áhuga."

Svava tók miklum framförum í tjáningarorðaforða á íhlutunartímabilinu og hækkaði sig um 19 orð en viðhélt peim orðaforða ekki að fullu og lækkaði um sex orð í viðhaldsmælingunni. Í viðtökuorðaforðanum hafði hún bætt við sig tíu orðum við lok íhlutunar og bætti einu orði við í viðhaldsmælingunni. Svava hélt pví stöðu sinni innan hópsins og var fyrir og eftir íhlutun með annan besta árangurinn á eftir Gunnari. 


\section{Sara}

Foreldrar Söru taka lítinn pátt í íslensku samfélagi og mæting Söru í leikskólann er ekki góð. Sara á eitt yngra systkini og er ekki vinmörg. Sara var pað barn sem hafði minnstan orðaforða fyrir íhlutun. Í tjáningarorðaforða pekkti hún 12 orð og 34 orð í viðtökuorðaforða.

Sara sýndi lítinn áhuga á verkefninu og var líka oft fjarverandi, prátt fyrir að rætt hafi verið við foreldra hennar og peir beðnir um að sjá til pess að hún mætti vel svo hún gæti tekið pátt í verkefninu. 10. desember 2019 skráir rannsakandi í dagbókina: „Sara er búin að missa af sjö tímum og er að fara óvænt til útlanda núna eftir prjá daga og missir pví af restinni af íhlutuninni (ein og hálf vika). Ég parf að mæta heim til hennar með skimunina strax eftir íhlutun ef hún mætir ekki meira í leikskólann. Petta tel ég hafa mikil áhrif á niðurstöður hennar í rannsókninni. Mætingin hjá henni hefur áhrif á hvernig henni tekst að fylgjast með efninu sem er verið að leggja upp með og hefur hún átt erfitt með að taka pátt í stundunum vegna pess að hún tengir ekki við efnið og hefur misst mikið úr.“

Prátt fyrir petta tók Sara góðum framförum meðan á íhlutuninni stóð og bætti við sig 12 orðum í tjáningarorðaforða og 14 orðum í viðtökuorðaforða. Í tjáningarorðaforða var hún komin upp fyrir Óla en í viðtökuorðaforða var hún enn lægst af börnunum fimm. Viðtökuorðaforðinn hélt velli og á viðhaldsmælingunni hafði hún bætt við sig tveimur orðum, en í tjáningarorðaforðanum lækkaði hún hins vegar um sex orð. Par hefur án efa haft áhrif að hún fór til útlanda með foreldrum sínum pegar íhlutuninni var að ljúka og var pví ekki í íslensku málsamfélagi í nokkrar vikur.

\section{Óli}

Foreldrar Óla eru nokkuð virkir í samfélaginu. Óli á engin systkini en er sterkur félagslega og á íslenska leikfélaga bæði innan og utan leikskólans. Einnig á hann leikfélaga sem tala sama móðurmál og hann. Óli var með frekar slakan tjáningarorðaforða fyrir íhlutun, pekkti 17 orð og var næstlægstur af börnunum. Viðtökuorðaforðinn var hins vegar í meðallagi en par pekkti hann 46 orð.

Óli var mjög áhugasamur og mætti vel í íhlutunina. Óli átti erfitt með að stjórna sér í krefjandi aðstæðum en vinnan í litlum hóp útivið hentaði honum vel. 26. nóvember 2019 skráir rannsakandi í dagbókina: „Ég sé pað alltaf betur og betur hvað svona lítill hópur hentar Óla vel. Hann parf mikið aðhald og pað er auðvelt að veita honum pað í pessum hópi. Hann er orkumikill og parf mikla hreyfingu sem ég get leyft honum að fá útrás fyrir pví við erum úti. Pað truflar hin börnin lítið." Óli komst upp á gott lag með að nota myndirnar til að hjálpa sér að ná tökum á íslenskunni. 4. desember 2019 skráir rannsakandi í dagbókina: „Рað hentar Óla mjög vel að vera með myndirnar til stuðnings við orðin. Hann tengir vel við myndirnar og held ég að pær hjálpi honum mikið við að muna orðin. Pá sérstaklega pau orð sem við sjáum ekki í okkar nærumhverfi.“" 4. desember 2019 skráir rannsakandi annað dæmi um hvernig Óli nýtir sér myndirnar: „Í dag var Óli að segja frá og mundi ekki alveg eitt orðið. Pá var hann fljótur að biðja um myndirnar og sýndi mér hvað hann var að meina. Petta gladdi mig og sýndi mér að myndirnar eru að hjálpa honum, pví um leið og hann sá myndina pá kom orðið hjá honum."

Framfarir í tjáningarorðaforða voru litlar hjá Óla á tímabilinu, eftir íhlutun hafði hann bætt tveimur orðum við tjáningarorðaforða sinn og tveimur mánuðum sỉðar hafði eitt orð bæst við. Í viðtökuorðaforðanum urðu hins vegar góðar framfarir. Eftir íhlutun hafði hann bætt sig um 16 orð og í viðhaldsmælingunni höfðu bæst við tvö orð til viðbótar.

\section{Jóna}

Foreldrar Jónu eru bádir virkir pátttakendur í samfélaginu. Jóna á systkini sem er aðeins eldra en hún. Hún á leikfélaga fyrir utan leikskólann sem er ekki með sama móðurmál og hún, pví tala pær íslensku sín á milli. Í leikskólanum á Jóna einnig nokkra íslenska vini sem hún leikur mikið við. Jóna var með ágætan orðaforða í upphafi verkefnisins. Í tjáningarorðaforða var hún með 23 orð fyrir íhlutun og 46 í viðtökuorðaforða. 
Jóna var nokkuð áhugasöm og mætti mjög vel en var einnig frekar áhrifagjörn og með lítið pol fyrir mótlæti. Hún var feimin og hlédræg sem hafði hamlandi áhrif á pátttöku hennar í málörvunarstundunum en utan peirra reyndi hún stundum að ná athygli kennara til að sýna kunnáttu sína eins og fram kemur í dagbókarfærslu 18. nóvember 2019: „Ég parf samt að passa upp á að Jóna fái tækifæri til að tjá sig og vera virk pví hún er frekar hlédræg og lætur fara lítið fyrir sér. Hún er mjög dugleg að koma til mín fyrir utan tímana og spjalla við mig. Hún verður mjög stolt af sjálfri sér pegar hún notar orð sem hún hefur lært í tímunum og segir mér að petta sé nýtt orð sem hún var að læra. Hún notar myndirnar mikið eins og Óli. Finnst mjög gott að styðja sig við pær pegar við erum í göngutúrunum.“

Framfarir í tjáningarorðaforða voru ekki ýkja miklar á íhlutunartímabilinu og hún bætti aðeins við sig tveimur orðum. Tveimur mánuðum síðar höfðu hins vegar bæst við fimm ný orð hjá henni. Framfarir í viðtökuorðaforða voru ágætar. Eftir íhlutun hafði hún hækkað sig um níu orð og í viðhaldsmælingunni höfðu fjögur orð til viðbótar bæst við.

\section{Hvaða orð pekkja börnin?}

Kannað var hvaða orð úr peim premur orðapemum sem unnið var með börnin höfðu á valdi sínu, pað er hvaða orð pau gátu nefnt pegar tjáningarorðaforði peirra var metinn fyrir íhlutun, strax eftir að íhlutun lauk og tveimur mánuðum síðar. Í ljós kom að börnin pekktu ákveðin orð frekar en önnur og sum orðanna pekkti ekkert barnanna.

Eins og fram hefur komið var orðapemað veður pað orðapema sem börnin pekktu hlutfallslega flest orð í, bæði fyrir og eftir íhlutun. Eins og sjá má á Mynd 5 pekktu öll börnin fjögur af sjö orðum úr pví orðapema áður en íhlutun hófst, pað er orðin sól, snjókoma, rigning og kalt, fjögur af fimm börnum pekktu líka orðið heitt fyrir íhlutun og tvö börn pekktu orðin vindur og ský. Að íhlutun lokinni pekktu öll börnin öll orðin en í viðhaldsmælingunni hafði eitt barn tapað orðinu vindur og eitt orðinu ský.

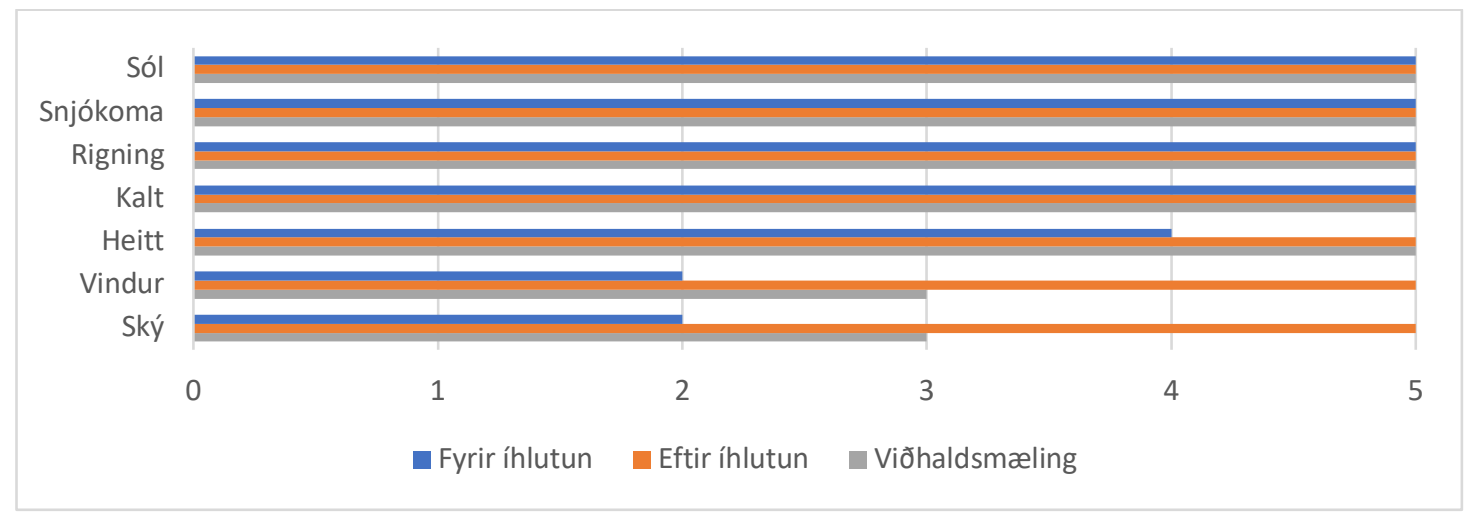

Mynd 5. Orð úr orðapemanu veður sem börnin pekktu fyrir og eftir íhlutun.

Á Mynd 6 má sjá hvaða orð úr orðapemanu útileiksvaði börnin pekktu fyrir og eftir íhlutun. Öll börnin gátu nefnt prjú af 16 orðum fyrir íhlutun en pað voru orðin skófla, róla og hjól, fjögur af fimm börnum pekktu líka orðin sandur, sandkassi og rennibraut og prjú börn pekktu orðið fótbolti. Eftir íhlutun gátu öll börnin nefnt pessi orð. Önnur orð pekktu færri börn. Tvö börn pekktu orðin körfubolti og fata fyrir íhlutun, eitt barn orðið kastali og ekkert barnanna pekkti orðin klifurgrind, príhjól, hlaupahjól, kritar eða útivera. Eftir íhlutun var aðeins eitt barn sem nefndi orðið útivera og tvö sem nefndu orðið kritar en fleiri pekktu önnur orð sem spurt var um. Í viðhaldsmælingunni höfðu orðið enn frekari framfarir. Í viðbót við pau orð sem öll börnin kunnu eftir íhlutun pekktu pau nú öll orðin körfubolti, fata og hlaupahjól og einnig pekktu fleiri börn orðin leikvöllur, príhjól og kritar. 


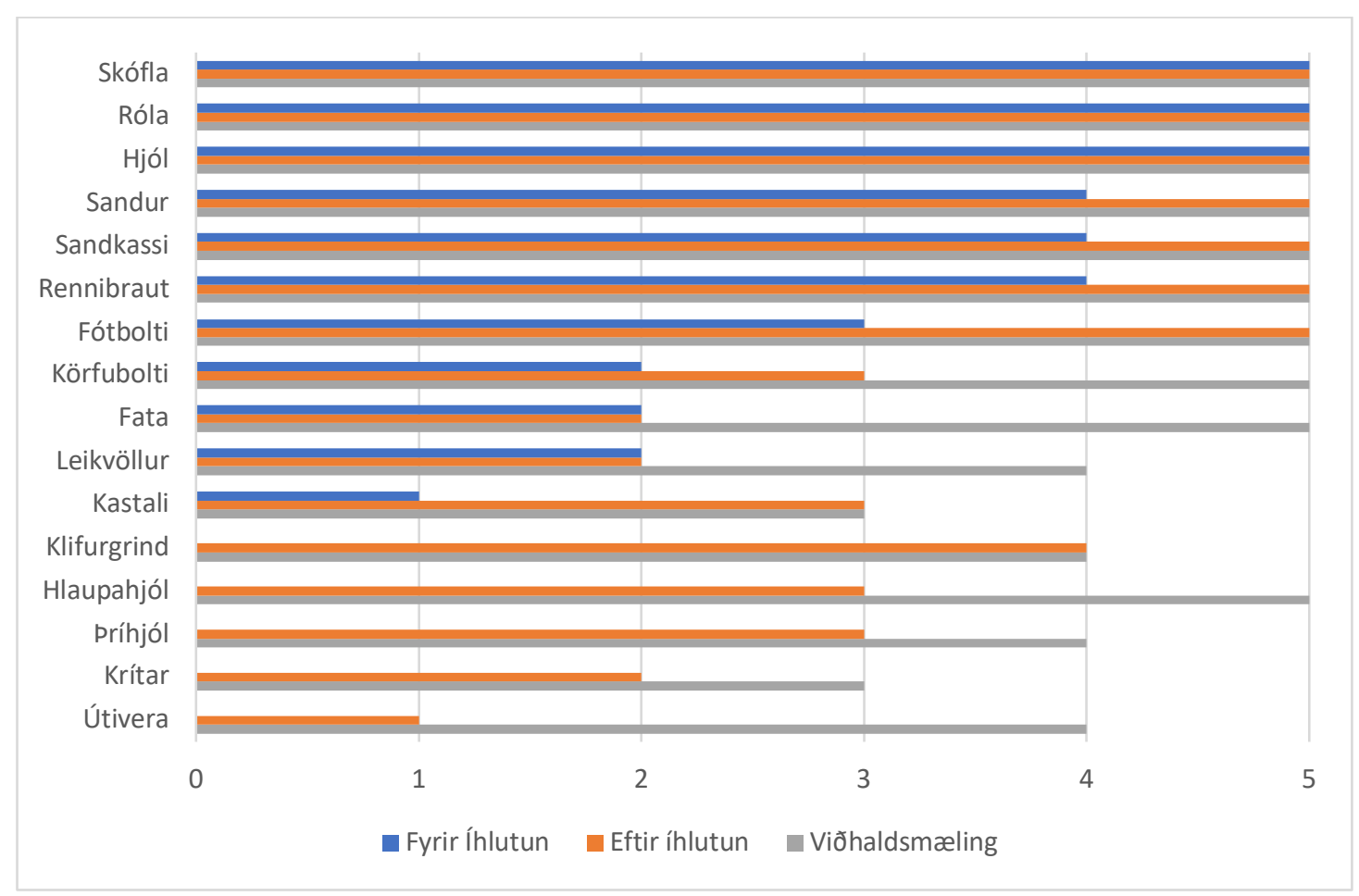

Mynd 6. Orðin úr orðapemanu útileiksvæði sem börnin pekktu fyrir og eftir íhlutun.

Orðapemað umhverfið úti var pað sem börnin pekktu hlutfallslega frest orð úr, en pað orðapema var líka langstærst og taldi 47 orð. Á Mynd 7 má sjá hvaða orð börnin pekktu fyrir og eftir íhlutun. Fyrir íhlutun voru aðeins tvö orð úr pessu orðapema sem öll börnin pekktu en pað voru orðin tré og blóm. Fjögur af fimm börnum pekktu líka orðin gras, fjall og steinn og prjú börn pekktu orðið brú. Önnur orð pekktu fá eða engin börn. Eftir íhlutun hafði peim orðum sem börnin pekktu fjölgað mikið, en pað var mjög mismunandi milli barna hvaða orðum pau höfðu bætt í orðaforða sinn. Viðhaldsmælingin bendir til pess að pessi orðaforði sé viðkvæmari en orðaforðinn úr hinum orðapemunum tveimur og pau hafi ekki fest sig eins vel í sessi hjá börnunum. Meðaltal hópsins fyrir orð sem pau pekktu strax eftir íhlutun og tveimur mánuðum síðar er nánast pað sama, 12 orð eftir íhlutun og 13 orð tveimur mánuðum síðar, en pað eru ekki nákvæmlega sömu orðin sem skýrist af pví að sum barnanna töpuðu orðum úr pessum flokki á meðan önnur bættu við sig orðum.

\section{Umræða}

Markmið rannsóknarinnar var að kanna hvort markvissar málörvunarstundir í útikennslu með námsefninu Orðaleik hefðu mælanleg áhrif á orðaforða barnanna um veður, útileiksvæði og umhverfi barnanna utanhúss. Meginniðurstöður rannsóknarinnar voru pær að íhlutunin skilaði árangri, orðaforði barnanna jókst á tímabilinu og pau viðhéldu peim orðaforða að miklu leyti tveimur mánuðum síðar. Niðurstöður sýndu pó jafnframt að pau áttu misauðvelt með að læra orðin úr orðapemunum premur og framfarir einstakra barna voru mismiklar.

\section{Einstaklingsmunur í orðaforða og framförum}

Pótt öllum börnunum færi fram á peim tíma sem rannsóknin stóð yfir voru framfarir peirra mismiklar. Hjá Óla og Jónu urðu litlar framfarir í tjáningarorðaforða á rannsóknartímanum og Jóna bætti líka færri orðum við viðtökuorðaforðann á tímabilinu en hin börnin. Pegar pátttaka pessara barna í málörvunarstundunum er skoðuð kemur fram að pótt Óli væri áhugasamur og mætti vel í málörvunarstundirnar átti hann oft erfitt með einbeitingu sem getur hafa haft áhrif á hve vel hann tileink- 
Netla - Veftímarit um uppeldi og menntun:

Sérrit 2021 - Menntakvika 2021

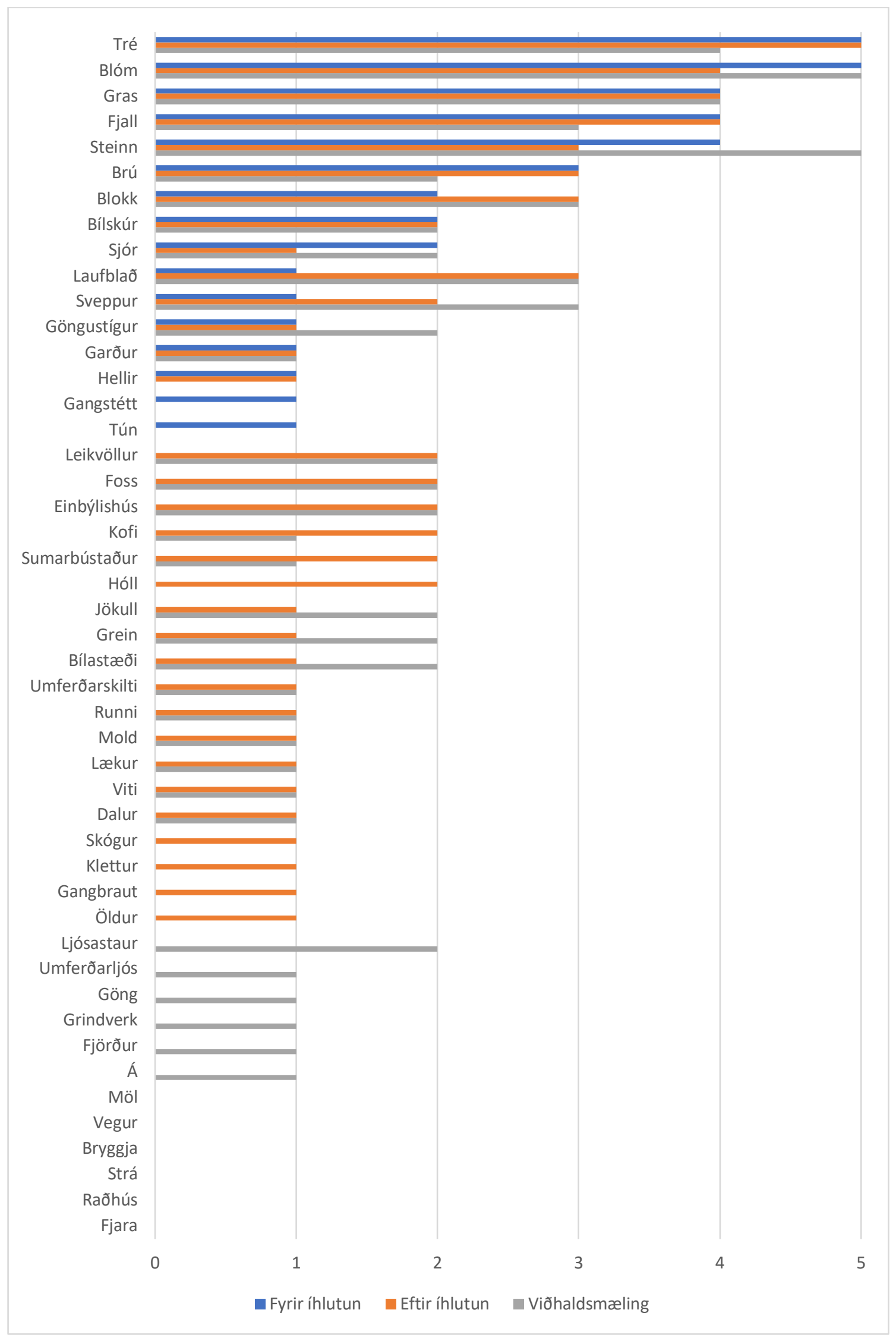

Mynd 7. Orðin úr orðapemanu umbverfið úti sem börnin pekktu fyrir og eftir íhlutun. 
aði sér pað sem fram fór og Jóna var feimin og hlédræg sem hafði hamlandi áhrif á pátttöku hennar. Gunnar sem var hæstur í tjáningarorðaforða bæði í upphafi og við lok rannsóknarinnar og hæstur í viðtökuorðaforða ásamt Svövu var aftur á móti ófeiminn og mjög virkur í málörvunarstundunum, jafnvel svo virkur að önnur börn áttu erfitt með að komast að eins og fram kom í dagbókarfærslu. Fyrri rannsóknir hafa sýnt að til að börn festi orð í sessi er mikilvægt að pau taki sjálf virkan pátt í umræðum par sem orðin eru notuð (McKeown og Beck, 2014; Zevenbergen og Whitehurst, 2003). Niðurstöður rannsóknarinnar renna stoðum undir að virkni barnanna skipti máli og eru áminning um að kennarar geri allt sem í peirra valdi stendur til að virkja öll börnin í umræðum og tjáningu í málörvunarstundum sem og daglegu leikskólastarfi. Í pví sambandi parf að huga sérstaklega að peim börnum sem halda sig til hlés eða sýna lítinn áhuga pví pau purfa enn meiri hvatningu en pau börn sem eru öruggari með sig - pau sækja sér má segja æfinguna sjálf.

Athygli vekur að Sara sem missti af stórum hluta málörvunarstundanna náði engu að síður góðum framförum á íhlutunartímanum. Hún var samt enn með slakasta orðaforðann eftir íhlutun og viðhélt tjáningarorðaforðanum ekki eins vel eftir íhlutun og flest hinna barnanna, enda fór hún til útlanda með foreldrum sínum í nokkrar vikur strax að íhlutuninni lokinni. Framfarir hennar sýna að kennsla eins og pessi í leikskólanum getur skipt sköpum fyrir pau börn sem standa höllum fæti og fá lítinn stuðning eða hvatningu frá foreldrum hvað íslenskunámið varðar. Foreldrar Söru eru í litlum tengslum við íslenskt samfélag og eins og fram hefur komið mætti hún verr í leikskólann en hin börnin. Рað kemur pví ekki á óvart að íslenskur orðaforði hennar sé slakari en hinna barnanna pví rannsóknir hafa sýnt að tíminn sem tvítyngd börn verja í málumhverfi hvers tungumáls og gæði peirrar málörvunar sem pau fá skiptir sköpum fyrir pað hve góðum tökum pau ná á hvoru tungumáli fyrir sig (Thordardottir, 2011). Sara tilheyrir pví hópi barna sem leggja parf sérstaka rækt við í leikskólastarfinu til að tryggja að pau fái nægilega gott innlegg í íslenskuna til að ná grunntökum á málinu.

\section{Hvaða orð lærðu börnin?}

Mælingar á orðaforða barnanna í upphafi rannsóknarinnar sýndu að pau skildu öll orðin í orðapemanu veðrið, gátu nefnt mörg peirra og í lok íhlutunar voru pau orðin örugg á peim orðum sem upp á vantaði. Í forprófunum skildu pau líka flest orðanna úr orðapemanu útileiksveðið en gátu aðeins nefnt lítinn hluta peirra sjálf. Að íhlutun lokinni pekktu pau nær öll orðin og gátu nefnt um og yfir helming peirra. Umbverfið úti var pað orðapema sem reyndist börnunum erfiðast. Fyrir íhlutun pekktu börnin aðeins lítið brot af peim orðum og flest peirra gátu aðeins nefnt nokkur peirra. Góðar framfarir urðu í pessu orðapema hjá Gunnari og Svölu og gátu pau nefnt um helming orðanna eftir íhlutun. Jóna og Óli pekktu hins vegar færri orð úr pessu orðapema eftir íhlutun en fyrir hana og Sara bætti aðeins við sig nokkrum orðum.

Pekking barnanna og framfarir endurspegla vel hvernig börn læra orð í gegnum daglegt líf og athafnir (Bloom, 2000). Orðin sem pau pekktu í upphafi rannsóknarinnar eru orð sem eru mikið notuð í daglegu tali og standa fyrir hluti og fyrirbæri sem börnin pekkja af eigin raun. Pað er til dæmis mikið unnið með veðrið í leikskólastarfinu. Daglega var valinn veðurfræðingur sem setti fram veðurspá fyrir daginn, fann til pau spjöld sem pössuðu við veðrið og sagði hinum börnunum hvernig veðrið var. Pau orð sem eru í orðapemanu útileiksvæði tilheyra líka öll reynsluheimi barnanna og koma oft fyrir í daglegu tali í leikskólanum og pað kemur pví ekki á óvart að börnin hafi átt auðvelt með að taka pau inn í orðaforða sinn. Par sést líka að framfarirnar halda áfram eftir að íhlutun lýkur. Рað var orðapemað umbverfið úti sem vafðist mest fyrir börnunum. Í pví orðapema er nokkuð af orðum sem börnin hafa litla eða enga tengingu við og hafa kannski aldrei séð og heyrt um vegna landfræðilegrar legu bæjarfélagsins. Í pessu orðapema voru einnig fleiri orð en í hinum tveimur eða 47 orð og sennilega hefði purft að gefa sér lengri tíma til að vinna með pað orðapema en hin. Pegar skoðað er hvaða orð börnin pekktu helst og hver síður sést að börnin pekktu ákveðin orð frekar en önnur. Fyrir íhlutun pekktu flest börnin orðin tré, blóm, steinn, fjall, gras og brú sem allt eru orð sem tengjast peirra nánasta umhverfi. Á íhlutunartímanum bættu pau við sig fleiri orðum úr pessum flokki en vel 
má sjá að pað hvaða orð pau tileinkuðu sér réðst af pví hve vel pau gátu tengt við orðin og merkingu peirra. Að íhlutun lokinni gat til dæmis ekkert barnanna nefnt orðin fjara og bryggja sem kemur sennilega til af pví að pau búa inni í landi og pekkja ekki fjöruna og bryggjur af eigin raun. Petta eru einnig orð sem koma ekki mjög oft fyrir í daglegu tali í leikskólanum. Pað kemur heim og saman við niðurstöður fyrir rannsókna sem sýna að mikilvægt er að börnin geti tengt við merkingu orðanna sem verið er að kenna peim (Honig, 2017) og par reynir í mörgum tilvikum á útsjónarsemi kennaranna í að útskýra orðin og koma peim inn í orðaforða barnanna. Framfarirnar sem urðu á peim sjö vikum sem íhlutunin stóð yfir sýnir að með pví að vinna á markvissan hátt með valin orðapemu er hægt að tryggja að börnin heyri fleiri og önnur orð en annars hefðu komið fyrir í málumhverfi peirra.

\section{Námsefnið Orðaleikur og útinám}

Að vera úti og vinna með orð sem tengjast útiveru á einn eða annan hátt reyndist vel. Börnin gátu tengt við flest orðin með pví að sjá pað sem pau standa fyrir, koma við pað og jafnvel smakka á pví. Pannig fengu pau skýrari mynd af merkingu orðanna en ef aðeins hefði verið unnið með myndirnar úr Orðaleik, en pað að geta tengt saman orð og merkingu er lykillinn að pví að börn efli orðaforða sinn (Bloom, 2000). Pótt myndirnar í Orðaleik séu skýrar hefur pað ekki sama gildi að sjá hlut á mynd og að sjá hlutinn sjálfan, snerta hann eða kynnast honum á annan ápreifanlegan hátt. Útiveran og sú tenging við orðin sem varð til par átti pví án efa sinn pátt í að börnin náðu að bæta við orðaforða sinn á íhlutunartímanum.

Myndirnar reyndust börnunum líka vel til að læra orðin og pau áttuðu sig á hvernig pau gátu nýtt sér myndirnar sem stuðning við daglega tjáningu. Pannig bað Óli um myndirnar pegar hann var að segja kennara frá og mundi ekki orð sem hann ætlaði að nota, en um leið og hann sá myndina fann hann orðið. Jóna sem var feimin og hlédræg nýtti sér pað líka gjarnan að benda á myndirnar til að tjá hug sinn. Myndirnar opna börnunum pannig leið til tjáningar á meðan pau hafa ekki náð góðum tökum á talmálinu.

Börnin voru almennt áhugasöm í málörvunarstundunum og útiumhverfið hafði jákvæð áhrif á pau. Í dagbókarfærslum kom til dæmis fram að Óli, sem átti erfitt með einbeitingu og hafði mikla hreyfipörf, naut sín vel í útikennslunni sem er í samræmi við aðrar rannsóknir á jákvæðum áhrifum útiumhverfis á hegðun og einbeitingu barna (Taylor og Kuo, 2011). Pað er aftur áminning um að nýta ætti sem best pau námstækifæri sem gefast í útiverunni og tengja til dæmis málörvun með markvissum hætti inn í pað sem börnin fást við úti eins og gert var hér.

\section{Lokaorð}

Rannsóknin sem hér hefur verið sagt frá náði aðeins yfir nokkurra vikna tímabil og til fimm tvítyngdra barna. Niðurstöður hennar sýna engu að síður að markviss orðaforðakennsla skilar fljótt árangri. Námsefnið Orðaleikur er vel til pess fallið að vinna með málörvun tvítyngdra barna en mikilvægt er að tengja pá vinnu við annað starf leikskólans og kenna orðin í merkingarbæru samhengi líkt og hér var gert. Sést pað til dæmis á að pau orð sem börnin gátu ekki tengt við umhverfi sitt lærðu pau síður en pau orð sem pau gátu tengt við hluti og athafnir í nærumhverfi sínu. 


\section{Learning Icelandic as a second language: Vocabulary instruction in outdoor teaching}

The number of immigrants in Iceland has increased significantly in recent years. A few years ago, almost all children in Icelandic preschools were monolingual Icelandic children, while now in 2021 about $15 \%$ of preschool children are immigrant children learning Icelandic as a second language. Studies on Icelandic vocabulary knowledge of immigrant children in Iceland have shown that their vocabulary is considerably smaller than that of their monolingual Icelandic peers. Studies also indicate that Icelandic preschool teachers need more support and teaching materials to teach Icelandic as a second language. Specialists at Centre of School Development at the University of Akureyri have, in the past three years, developed dedicated teaching material called Orðaleikur which is intended to support the teaching of Icelandic as a second language in preschool. Orðaleikur consists of a gallery of pictures showing things relating to preschool and the daily life of young children, and a collection of assignments and ideas that can be used with children to work with the words in the gallery.

The aim of this study was to evaluate the effect of vocabulary teaching with the teaching material Ordaleikur in outdoor teaching. The research questions were: 1) Is the teaching material Orðaleikur suitable for strengthening children's vocabulary? And 2) What effect does the teaching have on the children's vocabulary?

Five 4-5 year old children who were learning Icelandic as their second language, received targeted vocabulary teaching for seven weeks. In each week the children had two or three 45-60 min long lessons with their teacher, focusing on teaching a special vocabulary. Three word-groups from Orðaleikur were chosen to work with, words about weather, outdoor environment, and outdoor play areas. The teaching took place outdoor as the words taught related to things and phenomena in the outdoor environment. Conversations and games were then used to help the children to learn and remember the new words.

The children's progress was assessed by measuring receptive and productive vocabulary, before intervention, at the end of the intervention period and two months after the intervention ended. Their teacher also kept a research journal to record their participation and progress. Results showed progress in both receptive and productive vocabulary during the intervention period and the children maintained that vocabulary two months later. Some words were learned more easily than others. Not surprisingly the children learned words standing for things and ideas in their daily environment (e.g., jungle gym, playground) more easily than words indicating things or ideas less closely related to their daily life (e.g., pier, fjord). Although all the children showed progress in vocabulary knowledge, significant individual differences were found in vocabulary knowledge and progress over the intervention period. From data in the research journal, it can be concluded that the children's level of activity in lessons affects their vocabulary progress. The children who were enthusiastic and active in conversations with other children and adults in the vocabulary lessons showed better progress than those who took less interest in the project or were too shy to take part in conversations.

The results confirm that using the teaching material in Orðaleikur to work with a specially selected vocabulary in context in the preschool is an effective way to strengthen young children's vocabulary. However, teachers should bear in mind that the participation of the whole class is important for their learning and ensure that all children are active in lessons. Special attention should be paid to those children who show little interest or are shy, encouraging them to take part in conversations with adults and other children in the preschool.

Key words: Vocabulary, second language learning, vocabulary instruction, outdoor teaching 


\section{Um höfunda}

Harpa Sif Porsteinsdóttir (harpasif@hvolsvollur.is) er deildarstjóri á Leikskólanum Örk á Hvolsvelli. Hún lauk B.Ed.-prófi í leikskólakennarafræðum frá Háskólanum á Akureyri árið 2018 og í framhaldi af pví meistaraprófi í leikskólakennarafræðum frá sama skóla árið 2020. Harpa Sif hefur unnið á leikskólanum Örk síðan 2014.

Rannveig Oddsdóttir (rannveigo@unak.is) er lektor við kennaradeild Háskólans á Akureyri. Hún lauk leikskólakennaranámi frá Fósturskóla Íslands 1994, meistaraprófi frá Kennaraháskóla Íslands með áherslu á sérkennslu 2004 og doktorsprófi frá Menntavísindasviði Háskóla Íslands 2018. Rannveig kenndi um árabil í leik- og grunnskólum en hefur undanfarin ár sinnt kennslu, rannsóknum og ráðgjöf við Menntavísindasvið Háskóla Íslands og Háskólann á Akureyri. Rannsóknir hennar hafa einkum beinst að málproska, læsi og ritun leik- og grunnskólabarna.

\section{About the authors}

Harpa Sif Porsteinsdóttir (harpasif@hvolsvollur.is) is a preschool department head at Leikskólinn Örk in Hvolsvöllur. She completed a bachelor's degree in early childhood education in 2018 from The University at Akureyri and a master's degree in early childhood education in 2020. She has worked as a preschool teacher in Leikskólinn Örk from 2014.

Rannveig Oddsdóttir (rannveigo@unak.is) is an assistant professor at the University of Akureyri. She graduated as a preschool teacher from the Iceland College for Early Childhood Educators in 1994, completed a master's degree in pedagogy and education from the Iceland University of Education in 2004 and a PhD from the University of Iceland in 2018. Her main research interests lie in the development of language, literacy and writing among preschool and primary school children.

\section{Heimildir}

Amalía Björnsdóttir, Ingibjörg Símonardóttir og Jóhanna Einarsdóttir. (2003). Próun HLJÓM-2 og tengsl pess við lestrarfærni og ýmsa félagslega pætti. Uppeldi og menntun, 12, 9-30.

Aneta Figlarska, Rannveig Oddsdóttir, Samúel Lefever og Hrafnhildur Ragnarsdóttir. (2017). Pólskur og íslenskur orðaforði tvítyngdra leikskólabarna: Málumhverfið heima og í leikskólanum. Rádstefnurit Netlu - Menntakvika 2017. http:/netla.hi.is/serrit/2017/menntakvika_2017/007.pdf

Attig, M. og Weinert, S. (2020). What impacts early language skills? Effects of social disparities and different process characteristics of the home learning environment in the first 2 years. Frontiers in Psychology, 11. https://doi.org/10.3389/fpsyg.2020.557751

Bialystok, E., Luk, G., Peets, K. F. og Yang, S. (2010). Receptive vocabulary differences in monolingual and bilingual children. Bilingualism: Language and Cognition, 13(4), 525-531. https://doi. org/10.1017/s1366728909990423

Biemiller, A. og Boote, C. (2006). An effective method for building meaning vocabulary in primary grades. Journal of Educational Psychology, 98(1), 44-62. https://doi.org/10.1037/0022-0663.98.1.44

Bloom, P. (2000). How children learn the meanings of words. MIT Press.

Bowers, E. P. og Vasilyeva, M. (2011). The relation between teacher input and lexical growth of preschoolers. Applied Psycholinguistics, 32(1), 221-241. https://doi.org/10.1017/S0142716410000354 
Cirino, P. T., Pollard-Durodola, S. D., Foorman, B. R., Carlson, C. D. og Francis, D. J. (2007). Teacher characteristics, classroom instruction, and student literacy and language outcomes in bilingual kindergartners. The Elementary School Journal, 107(4), 341-364. https://doi.org/10.1086/516668

Cummins, J. (2001). Bilingual children's mother tongue: Why is it important for education? Sprogforum, 7(19), 15-20.

Edyburn, K. L., Quirk, M. og Oliva-Olson, C. (2019). Supporting Spanish-English bilingual language development among Latinx dual language learners in early learning settings. Contemporary School Psychology, 23, 87-100. https://doi.org/10.1007/s40688-018-0209-7

Eiríkur Rögnvaldsson. (2020, 16. febrúar). Tölum íslensku við útlendinga. Eiríkur Rögnvaldsson prófessor emeritus i islenskri málfreði við Háskóla Íslands. https://uni.hi.is/eirikur/2020/02/16/tolum-islensku-vid-utlendinga/

Gathercole, V. C. M. og Thomas, E. M. (2009). Bilingual first-language development: Dominant language takeover, threatened minority language take-up. Bilingualism: Language and Cognition, 12(2), 213-237. https://doi.org/10.1017/S1366728909004015

Grøver, V., Lawrence, J. og Rydland, V. (2018). Bilingual preschool children's second-language vocabulary development: The role of first-language vocabulary skills and second-language talk input. International Journal of Bilingualism, 22(2), 234-250. https://doi.org/10.1177/1367006916666389

Hart, B. og Risley, T. R. (1995). Meaningful differences in the everyday experience of young American children. Cambridge University Press.

Hermína Gunnpórsdóttir, Stéphanie Barillé og Markus Meckl. (2017). Nemendur af erlendum uppruna: Reynsla foreldra og kennara af námi og kennslu. Tímarit um uppeldi og menntun, 26(1-2), 21-41. https://tum.hi.is/wp-content/uploads/2020/05/2685-3769-2-PB.pdf

Hoff, E. (2006). How social contexts support and shape language development. Developmental Review, 26(1), 55-88. https://doi.org/10.1016/j.dr.2005.11.002

Hoff, E. og Core, C. (2013). Input and language development in bilingually developing children. Seminars in Speech and Language, 34(4), 215-226. https://doi.org/10.1055/s-0033-1353448

Honig, A. S. (2017). Outdoors in nature: Special spaces for young children's learning. Early Child Development and Care, 189(4), 659-669. https://doi.org/10.1080/03004430.2017.1337609

Hrafnhildur Ragnarsdóttir. (2015). Málproski leikskólabarna. Próun orðaforða, málfræði og hlustunarskilnings milli fjögurra og fimm ára aldurs. Netla - Veftimarit um uppeldi og menntun. http:// netla.hi.is/greinar/2015/ryn/007.pdf

Hrafnhildur Ragnarsdóttir. (2018). Orðaforði íslenskra barna frá 4 til 8 ára aldurs: Langtímarannsókn á vaxtahraða og stöðugleika. Netla - Veftimarit um uppeldi og menntun. https://netla.hi.is/greinar/2018/ryn/15.pdf

Huttenlocher, J., Waterfall, H., Vasilyeva, M., Vevea, J. og Hedges, L. V. (2010). Sources of variability in children's language growth. Cognitive Psychology, 61(4), 343-365. https://doi.org/10.1016/j. cogpsych.2010.08.002

Kristín Norðdahl. (2016). Hlutverk útiumhverfis í námi barna. Sérrit Netlu 2016 - Um útinám. https://netla.hi.is/serrit/2015/um_utinam/05_15_utinam.pdf

Marulis, L. M. og Neuman, S. B. (2010). The effects of vocabulary intervention on young children's word learning: A meta-analysis. Review of Educational Research, 80(3), 300-334. https://doi. org/10.3102/0034654310377087 
McKeown, M. G. og Beck, I. L. (2014). Effects of vocabulary instruction on measures of language processing: Comparing two approaches. Early Childhood Research Quarterly, 29(4), 520-530. https:// doi.org/10.1016/j.ecresq.2014.06.002

Meisel, J. M. (2004). The bilingual child. Í T. K. Bhatia og W. C. Ritchie (ritstjórar), The handbook of bilingualism (bls. 91-113). Blackwell.

Mieszkowska, K., Luniewska, M., Kolak, J., Kacprazak, A., Wodniecka, Z. og Haman, E. (2017). Home language will not take care of itself: Vocabulary knowledge in trilingual children in the United Kingdom. Frontiers in Psychology, 8, 1358. https://doi.org/10.3389/fpsyg.2017.01358

Oroujlou, N. og Vahedi, M. (2011). Motivation, attitude, and language learning. Procedia - Social and Behavioral Sciences, 29, 994-1000. https://doi.org/10.1016/j.sbspro.2011.11.333

Ómar Hjalti Sölvason, Porlákur Axel Jónsson og Markus Hermann Meckl. (2021). Væntingar Íslendinga og hugmyndir innflytjenda um aðlögun innflytjenda að íslensku samfélagi. Íslenska pjóðfélagið, 12(1), 51-71.

Ramírez, R., Huang, B. H., Palomin, A. og McCarty, L. (2021). Teachers and language outcomes of young bilinguals: A scoping review. Language Speech and Hearing Services in Schools, 52(2), 755-768. https://doi.org/10.1044/2020_LSHSS-20-00066

Ramírez, R., López, L. M. og Ferron, J. (2019). Teacher characteristics that play a role in the language, literacy and math development of dual language learners. Early Childhood Education Journal, 47, 85-96. https://doi.org/10.1007/s10643-018-0907-9

Rannveig Oddsdóttir og Íris Hrönn Kristinsdóttir. (2018). Orðaleikur: Orðaforðanám i leikskóla. https://ordaleikur.msha.is

Rowe, M. L. (2012). A longitudinal investigation of the role of quantity and quality of child-direct speech in vocabulary development. Child Development, 83(5), 1762-1774. https://doi.org/10.1111/j. 1467-8624.2012.01805.x

Sigríður Ólafsdóttir. (2015). The development of vocabulary and reading comprehension among Icelandic second language learners [doktorsritgerð,, Háskóli Íslands]. http://hdl.handle.net/1946/23061

Sigríður Sigurjónsdóttir. (2005). Máltaka og setningafræði. Í Höskuldur Práinsson (ritstjóri), Íslensk tunga - III. bindi: Setningar (bls. 636-655). Almenna bókafélagið.

Sigrún Alda Sigfúsdóttir, Jóhanna T. Einarsdóttir, Porlákur Karlsson og Íris Ösp Bergpórsdóttir. (2020). Orðaforðakennsla með sögulestri fyrir börn með málproskaröskun. Netla - Veftímarit um uppeldi og menntun. https://netla.hi.is/greinar/2020/ryn/04.pdf

Sigrún Helgadóttir og Páll Jakob Líndal. (2010). Maður og náttúra. Náttúrufreðingurinn, 79(1-4), 95-101.

Solari, E. J., Zucker, T. A., Landry, S. H. og Williams, J. M. (2016). Relative effects of a comprehensive versus reduced training for Head start teachers who serve Spanish-speaking English learners. Early Education and Development, 27(7), 1060-1076. https://doi.org/10.1080/10409289.2016.1158610

Taylor, A. F. og Kuo, F. E. (2011). Could exposure to everyday green spaces help treat ADHD? Evidence from children's play settings. Applied Psychology-Health and Well Being, 3(3), 281-303. https://doi.org/10.1111/J.1758-0854.2011.01052.X

Thordardottir, E. (2011). The relationship between bilingual exposure and vocabulary development. International Journal of Bilingualism, 15(4), 426-445. https://doi.org/10.1177/1367006911403202 
Thordardottir, E., Rothenbert, A., Rivard, M.-E. og Naves, R. (2006). Bilingual assessment: Can overall proficiency be estimated from separate measurement of two languages? Journal of Multilingual Communication Disorders, 4(1), 1-21. https://doi.org/10.1080/14769670500215647

Thordardottir, E. T. og Juliusdottir, A. G. (2013). Icelandic as a second language: A longitudinal study of language knowledge and processing by school-age children. International Journal of Bilingual Education and Bilingualism, 16(4), 412-435. https://doi.org/10.1080/13670050.2012.693062

Thygesen, M., Engemann, K., Holst, G. J., Hansen, B., Geels, C., Brandt, J. Pedersen, C. B. og Dalsgaard, S. (2020). The association between residential green space in childhood and development of attention deficit hyperactivity disorder: A population-based cohort study. Environmental Health Perspectives, 128(12), 127011. https://doi.org/10.1289/EHP6729

Unsworth, S. (2016). Quantity and quality of language input in bilingual language development. Í E. Nicoladis og S. Montanari (ritstjórar), Bilingualism across the lifespan: Factors moderating language proficiency (bls. 103-121). American Psychological Association.

Zauche, L. H., Thul, T. A., Mahoney, A. E. D. og Stapel-Wax, J. L. (2016). Influence of language nutrition on children's language and cognitive development: An integrated review. Early Childhood Research Quarterly, 36(suppl. C), 318-333. https://doi.org/10.1016/j.ecresq.2016.01.015

Zevenbergen, A. A. og Whitehurst, G. J. (2003). Dialogic reading: A shared picture book reading intervention for preschoolers. Í A. Van Kleeck, S. A. Stahl og E. B. Bauer (ritstjórar), On reading books to children: Parents and teachers (bls. 170-192). Routledge.

Harpa Sif Porsteinsdóttir og Rannveig Oddsdóttir. (2021).

Að læra íslensku sem annað mál: Markviss orðaforðakennsla í útinámi.

Netla - Veftímarit um uppeldi og menntun: Sérrit 2021 - Menntavika 2021.

Sótt af http://netla.hi.is/serrit/2021/menntavika_2021/02.pdf

DOI: https://doi.org/10.24270/serritnetla.2021.2 